\title{
Fournier's Gangrene Complicating Hematologic Malignancies:Literature Review and Treatment Suggestions
}

\author{
Giovanni D’Arena ${ }^{1}$, Giuseppe Pietrantuono ${ }^{1}$, Emilio Buccino ${ }^{2}$, Giancarlo Pacifico ${ }^{2}$ and Pellegrino Musto ${ }^{3}$ \\ ${ }^{1}$ Onco-Hematology and Stem Cell Transplantation Unit, IRCCS “Centro di Riferimento Oncologico della \\ Basilicata”, Rionero in Vulture (Pz), Italy \\ ${ }^{2}$ Surgical Department, "S. Giovanni di Dio” Hospital, Melfi (Pz), Italy \\ ${ }^{3}$ Scientific Direction, IRCCS “Centro di Riferimento Oncologico della Basilicata”, Rionero in Vulture (Pz), Italy
}

Correspondence to: Giovanni D’Arena, MD. Onco-Hematology and Stem Cell Transplantation Unit, IRCCS “Centro di Riferimento Oncologico della Basilicata”, Via Padre Pio n. 1, 85028 Rionero in Vulture (Pz), Italy. Tel: +39.0972.726521, FAX: +39.0972.726217. E-mail: giovannidarena@libero.it

Competing interests: The authors have declared that no competing interests exist.

Published: November 1, 2013

Received: August 18, 2013

Accepted: October 8, 2013

Citation: Mediterr J Hematol Infect Dis 2013, 5(1): e2013067, DOI: 10.4084/MJHID.2013.067

This article is available from: http://www.mjhid.org/article/view/12132

This is an Open Access article distributed under the terms of the Creative Commons Attribution License (http://creativecommons.org/licenses/by/2.0), which permits unrestricted use, distribution, and reproduction in any medium, provided the original work is properly cited.

Abstract. Fournier's gangrene (FG) is a rare but severe necrotizing fasciitis of the external genitalia that may complicate the clinical course of hematologic malignancies and sometimes may be the first sign of the disease. The clinical course of FG is very aggressive and the mortality is still high despite the improvement in its management. Early recognition of FG and prompt appropriate treatment with surgical debridement and administration of antibiotics are the cornerstone of the management of this very severe disease. A review of the scientific literature focusing on the topic of FG complicating hematologic disorders is reported

Introduction. Fournier's gangrene (FG) is a particular type of necrotizing fasciitis (NF) involving the external genitalia and perianal or perineal regions with an acute rapidly progressive and potentially fatal course. ${ }^{1}$ Despite the first description of this disease was probably made by Ippocrates, ${ }^{2}$ this disorder is associated to the name of Alfred Fournier, a Parisian dermatologist and venereologist who firstly reported on 5 cases of otherwise healthy young men with a rapidly progressive gangrene of the penis and scrotum without apparent cause. ${ }^{3}$

The term necrotizing soft tissue infection has more recently been proposed because of including all forms of the disease. ${ }^{4}$ In fact, necrotizing infection may involve all type of soft tissue while diagnostic and therapeutic approaches are similar, regardless the anatomic or depth of infection. ${ }^{5}$

FG is quite rare while mortality, despite advances in management, is still very high, ranging from 20 to $30 \%$, depending on the comorbidities and the early surgical debridement and use of antibiotics. ${ }^{6}$ Indeed, a study analyzing English literature collected 1,726 cases of FG diagnosed from 1950 and 1999 worldwide and found that mortality was $16 \%{ }^{7}$ Surprisingly, a higher mortality rate is reported in the last years. In fact, an unpublished study cited by Mallikarjuna et al, 
collecting 3,297 cases from 1950 to 2007, reported a mortality rate of $21.1 \%{ }^{6}$ Moreover, the mortality of FG seems to be higher in developed countries, such as America and Europe, than in underdeveloped countries. $^{7}$ Taken together, this data may reflect the impact on the pathogenesis of FG of antibiotic resistance due to the use/abuse of antibiotics in the last years.

FG may affects subjects from infancy to old age, either men and women (though less frequently). In the large series of FG patients reported by Eke the male:female ratio was $10: 1{ }^{7}$ This is probably due to the fact that in women perineal region may better drain through vaginal secretions.

In Table 1 are listed some of the most frequently conditions associated to FG. Diabetes has been reported with a prevalence ranging from 32 to $66 \%$ of patients with FG, while alcholism showed a prevalence ranging from 25 to $66 \% .^{8-11}$ Small vessel disease, defective phagocytosis, diabetic neuropathy, immunosuppression and poor hygiene have been considered to explain the relatively high incidence of FG in these patients. ${ }^{1}$

Table 1. Most common comorbidities as risk factors for FG
Diabetes
$\checkmark$ Alchoholism
$\checkmark$ Obesity
$\checkmark$ Low socioeconomic status
$\checkmark$ Acquired immune deficiecny syndrome (AIDA)
$\checkmark$ Malignancies
$\checkmark$ Malnutrition
$\checkmark$ Prolonged hospitalization for debilitating illness
$\checkmark \quad$ Liver disease as cirrhosis
$\checkmark$ Chemotherapy
$\checkmark \quad$ Intravenous drug use
$\checkmark$ Iatrogenic immunosuppression (i.e., chronic corticosteroid use)
$\checkmark \quad$ Systemic lupus erythematosus
$\checkmark$ Crohn disease

Pathogenesis and Clinical Presentation. Less than one fourth of cases of FG is now considered idiopathic. $^{1,8}$ Colorectal sources (30-50\% of cases), urogenital sources (20-40\% of cases), cutaneous infections and local trauma (20\% of cases) are frequently identified as the cause of FG. The infectious process is due, in the majority of cases, to multiorganism infection (spreptococcall and staphilococcal species, enterobacteriaceae, anaerobic organism, and fungi). FG involves firstly superficial and deep fascial planes of genitalia; subsequently it spreads along the anatomical facial planes and to overlying skin, while muscles are often spared. However, the early event of FG is a localized infection near to the portal entry followed by an obliterative endoarteritis with cutaneous and subcutaneous vascular necrosis, leading to local ischemia and further bacterial proliferation. Via Buck and Dartos fascia, the infection of superficial perineal fascia may then spread to penis and scrotum, and, via Scarpa fascia, to the anterior abdominal wall. Not surprisingly, testicular involvement is very rare because of testicular arteries originates directly from the aorta, with a blood supply independent from the affected region.

The clinical presentation of FG is quite variable and a sudden or insidious onset may be both seen, the latter being more rare. Usually the infection starts as a cellulitis adjacent to the portal of entry, commonly in the perineum or perineal region. A strong fetid odour always occurs. Scrotal swelling, erythema, purulence or wound discharge, crepitation of inflammed tissue (due to the presence of gas forming organisms), fever, and pain are also frequently seen. The patients can rapidly progress to sepsis and multiorgan failure, the most common cause of death.

Laor et al proposed a scoring system, the so-called FG severity index (FGSI), to predict the prognosis. ${ }^{12}$ Table 2 summarizes the clinical and laboratory parameters used. A score $>9$ is associated with $75 \%$ probability of death. On the contrary, a score $<9$ increases the probability of survival to $78 \%$ More recently, Yilmasilar et al updated the FGSI by adding

Table 2. Fournier's Gangrene Severity Index (FGSI)

\begin{tabular}{|l|c|c|c|c|c|}
\hline Variable/Score & 4 & 3 & 2 & 1 & $\begin{array}{c}0 \\
\text { (Normal values) }\end{array}$ \\
\hline Temperature $\left({ }^{\circ} \mathrm{C}\right)$ & $>41$ & $39-40.9$ & - & $38.5-38.9$ & $36-35.9$ \\
\hline Heart rate (beats/min) & $>180$ & $140-179$ & $110-139$ & - & $70-109$ \\
\hline Respiratory rate (breaths/min) & $>50$ & $35-49$ & - & $25-34$ & $12-24$ \\
\hline Serum sodium (mmol/L) & $>180$ & $160-179$ & $155-159$ & $150-154$ & $130-149$ \\
\hline Serum potassium (mmol/L) & $>7$ & $6-6.9$ & - & $5.5-5.9$ & $3.5-5.4$ \\
\hline $\begin{array}{l}\text { Serum creatinine }(\mathrm{mg} / 100 \mathrm{~mL}) \\
(\mathrm{x} \text { 2 for acute renal failure) }\end{array}$ & $<3.5$ & $2-3.4$ & $1.5-1.9$ & - & $0.6-1.4$ \\
\hline Hematocrit $(\%)$ & $<60$ & - & $50-59.9$ & $46-49.9$ & $30-45.9$ \\
\hline White blood cell count (/mm $\left.{ }^{3} \times 1000\right)$ & $>40$ & - & $20-39.9$ & $15-19.9$ & $3-14.9$ \\
\hline Serum bicarbonate $(\mathrm{mmol} / \mathrm{L})$ & $>52$ & $41-51.9$ & - & $32-40.9$ & $22-31.9$ \\
\hline
\end{tabular}

Extent of the disease (dissemination score): FG confined to the urogenital and/or anorectal region, add 1: FG confined to the pelvic region, add 2; FG extended beyond the pelvic region, add 6 . Age score: age $\geq 60$ years add 1 , while age $<60$ years, add 0 . This score, proposed in 1995 by Laor et al [12], is based on deviation from reference ranges of the above parameters. Age and extent of disease have been added in 
2010 by Yilmazlar et al [13] to improve the prognostic ability of FGSI. Each parameter is scored between 0 and 4, where the higher value indicates the greater deviation from normal. Score $>9$ correlates with increased mortality.

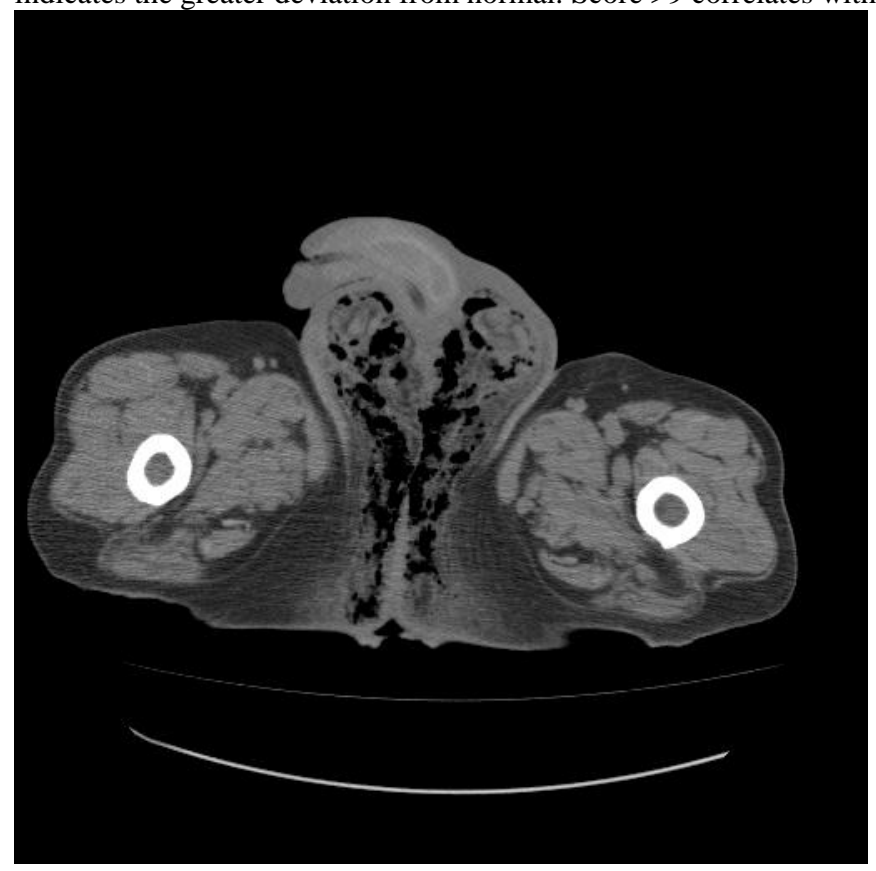

Figure 1. CT scan of a patient with FG showing emphysematous gangrene of perineum and scrotum (A).

two additional parameters, such as age and extent of the disease. ${ }^{13}$

Diagnosis and Management. The diagnosis of FG is usually made clinically. However, imaging may be particularly helpful to identify the rapidly progressing necrotizing process and the severity of the prognosis, that relies on the rapidity of diagnosis and the intense emergency management.

Computed tomography (CT) has a relevant importance in the diagnosis of FG because of its greater ability to identify and to evaluate the extent of the disease. CT scan can demonstrate asymmetric fascial thickening, coexisting fluid collection or abscess, fat stranding around the involved structures, and subcutaneous emphysema secondary to gasforming bacteria (Figure 1). ${ }^{14}$

Plain radiography may shows air within the tissue, while ultrasonography is able to differentiate intrascrotal abnormalities, may shows thickhened and swolled scrotal wall, containing gas inside. ${ }^{15}$

Essentials of successfull management of patients with FG include early recognition of the disease, complete surgical debridement and early institution of appropriate broad-spectrum antibiotic therapy and supportive care for hemodynamic stabilization.

Exploration and debridement must be undertaken as soon as possible. ${ }^{16,17}$ All necrotic tissue has to be removed (Figure 2). Because of testis are not involved, orchiectomy is performed rarely. Plastic reconstruction to provide skin cover may be useful to avoid infections and to accelerate the recovery.
Broad spectum antibiotic therapy, empiric initially and

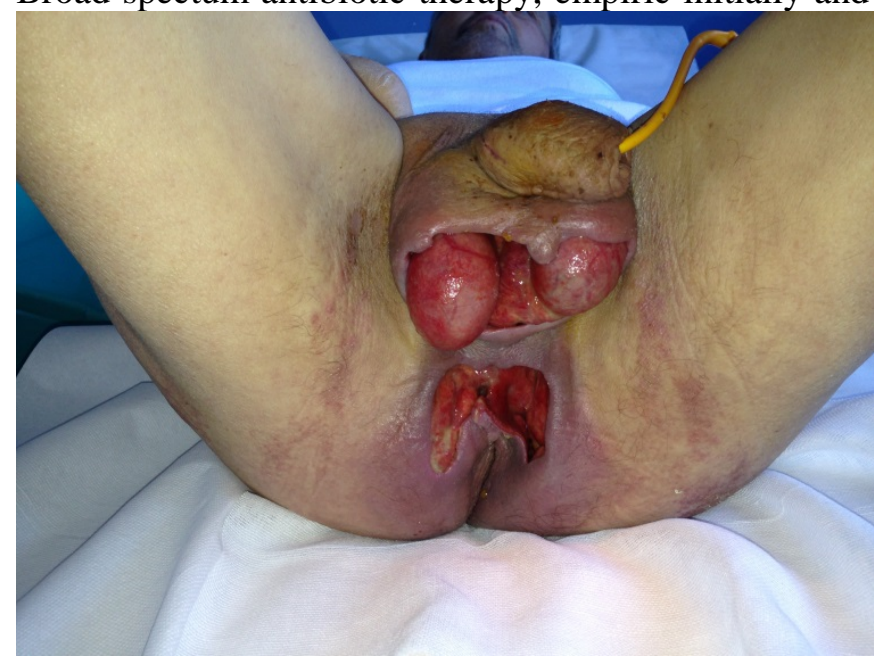

Figure 2. A case of FG after debridement with the complete excision of the necrotic tissue. The testicles are preserved.

then adjusted when culture results are available, need to be instituted as soon as possibile. The combination of third generation cefalosporins or aminoglycosides, plus penicillin and metronidazole is the therapy of choice. ${ }^{6}$ The combinations of antibiotics should be effective against staphylococcal and streptococcal bacteria, gram-negative, coliforms, pseudomonas, bacteroides, and clostridium. ${ }^{6}$ Clindamycin, linezolide, daptomycin, tigecycline, and carbopenem may be also used.

Finally, hyperbaric oxygen therapy may also be used in some selected cases, despite this therapeutic approach is still matter of debate. ${ }^{18}$

FG complicating hematologic disorders

We performed a review of the scientific literature focusing on the topic of Fournier's gangrene complicating hematologic malignancies. We searched the MEDLINE database using combinations of the following keywords: Fournier's gangrene, hematologic malignancies, acute lymphoblastic leukemia, acute myeloide leukemia, chronic lymphocytic leukemia, chronic myeloid leukemia.

To the best of our knowledge, only 35 cases of FG associated to hematologic malignancies have been described to date (Table 3). ${ }^{19-40}$ The mean age was 35 years (range 6-83 years). Thirty (86\%) patients were male, while only 3 patients $(14 \%)$ were female. The large majority of them (88\% of cases) were complications of previously diagnosed hematologic tumors, while only in 3 cases of acute myeloid leukemia (AML) and in 1 case of NHL FG was the first sign of the diseases. ${ }^{24,29,35}$ Twenty-two patients (63\% of all cases) had AML; among these, 13 had acute promyelocytic leukemia (APL), a unique subtype of AML classified as AML-M3 in the French-American- 
Bristish classification system, that has distinctive these cases FG was seen as a possible complication of morphological, biological and clinical features. In 12 of

Table 3. Published cases of patients with hematologic malignancies and FG

\begin{tabular}{|c|c|c|c|c|c|c|c|c|}
\hline Reference & Age & Sex & Disease & $\begin{array}{c}\text { First } \\
\text { sign/Complication }\end{array}$ & Note & $\begin{array}{l}\text { Isolated } \\
\text { bacteria }\end{array}$ & Specific therapy for FG & $\begin{array}{l}\text { Prognosis } \\
\text { of FG }\end{array}$ \\
\hline $\begin{array}{l}\text { Patrizi et } \\
\mathrm{al}^{19}\end{array}$ & 21 & $\mathrm{M}$ & APL & Complication & Pre-ATRA era & P.aeruginosa & Surgery, topical anti septic & Good \\
\hline Joo et $\mathrm{al}^{20}$ & 44 & $\mathrm{M}$ & ALL & Complication & & Not performed & $\begin{array}{l}\text { Patient died within hours of hospital } \\
\text { admission. }\end{array}$ & Died \\
\hline Berg et $^{21}$ & $\begin{array}{l}16 \\
25\end{array}$ & M & $\begin{array}{l}\text { DLBCL } \\
\text { AML }\end{array}$ & $\begin{array}{l}\text { Complication } \\
\text { Complication }\end{array}$ & & $\begin{array}{l}\text { P.aeruginosa } \\
\text { P.aeruginosa }\end{array}$ & $\begin{array}{l}\text { Surgery, penicillin and clindamycin. } \\
\text { Gentamicin, carbenicillin, } \\
\text { irradiation, surgery. }\end{array}$ & Died \\
\hline $\begin{array}{l}\text { Radaelli et } \\
\mathrm{al}^{22}\end{array}$ & $\begin{array}{l}37 \\
14\end{array}$ & $\begin{array}{l}\mathrm{M} \\
\mathrm{M}\end{array}$ & $\begin{array}{l}\text { AML } \\
\text { ALL } \\
\text { NHL } \\
\text { ALL }\end{array}$ & $\begin{array}{l}\text { Complication } \\
\text { Complication } \\
\text { Complication } \\
\text { Complication }\end{array}$ & & $\begin{array}{l}\text { P. rettgeri, P. } \\
\text { aeruginosa. } \\
\text { Negative tests } \\
\text { P.aeruginosa } \\
\text { P.aeruginosa }\end{array}$ & $\begin{array}{c}\text { Gentamicin, colistin, surgery. } \\
\text { Colistin, carbenicillin, } \\
\text { chloramphenicol, lincomycin, } \\
\text { surgery. } \\
\text { Colistin, amikacin, surgery. } \\
\text { Ceftazidime, amikacin, surgery, } \\
\text { hyperbaric oxygen therapy. }\end{array}$ & $\begin{array}{l}\text { Good } \\
\text { Died } \\
\text { Good } \\
\text { Good }\end{array}$ \\
\hline 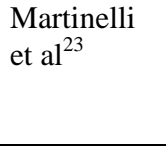 & $\begin{array}{l}41 \\
26\end{array}$ & $\begin{array}{l}\mathrm{M} \\
\mathrm{F}\end{array}$ & $\begin{array}{l}\text { AML } \\
\text { AML }\end{array}$ & & $\begin{array}{l}\text { Allogeneic } \\
\text { BMT } \\
\text { Allogeneic } \\
\text { BMT }\end{array}$ & $\begin{array}{l}\text { P.aeruginosa } \\
\text { P.aeruginosa }\end{array}$ & $\begin{array}{l}\text { Imipenem, surgery. } \\
\text { Amikacin, surgery }\end{array}$ & $\begin{array}{l}\text { Good } \\
\text { Good }\end{array}$ \\
\hline $\begin{array}{l}\text { Faber et } \\
\mathrm{al}^{24}\end{array}$ & 50 & $\mathrm{M}$ & APL & Firs sign & & E.coli & $\begin{array}{l}\text { Clindamycin, penicillin G, ciproxin, } \\
\text { surgery. }\end{array}$ & Died \\
\hline $\begin{array}{l}\text { Paydas et } \\
\mathrm{al}^{25}\end{array}$ & $\begin{array}{l}26 \\
26\end{array}$ & $\begin{array}{l}\mathrm{M} \\
\mathrm{F}\end{array}$ & $\begin{array}{l}\text { APL } \\
\text { APL }\end{array}$ & $\begin{array}{l}\text { Complication } \\
\text { Complication }\end{array}$ & $\begin{array}{l}\text { ATRA } \\
\text { therapy } \\
\text { ATRA } \\
\text { therapy }\end{array}$ & $\begin{array}{l}\text { Not found } \\
\text { Not reported }\end{array}$ & $\begin{array}{l}\text { Ceftriaxone, teicoplanin, } \\
\text { amphotericin B (to treat unknown } \\
\text { origin fever). } \\
\text { Ceftazidime, amikacin, } \\
\text { clindamycin. } \\
\end{array}$ & Good \\
\hline Levy et $\mathrm{al}^{26}$ & 44 & $\mathrm{M}$ & APL & Complication & & $\begin{array}{l}\text { S. faecalis, } \mathrm{S} \text {. } \\
\text { coagulase } \\
\text { negative }\end{array}$ & $\begin{array}{l}\text { Piperacillin/tazobactam, netilmicin, } \\
\text { vancomycin, amphotericin B, } \\
\text { metronidazol, surgery. }\end{array}$ & Died \\
\hline Goto et $\mathrm{al}^{27}$ & 43 & $\mathrm{M}$ & APL & Complication & $\begin{array}{l}\text { ATRA } \\
\text { therapy }\end{array}$ & Not reported & $\begin{array}{l}\text { Surgery, antibiotics therapy (not } \\
\text { otherwise specified) }\end{array}$ & Good \\
\hline $\begin{array}{l}\text { Yumura et } \\
\mathrm{al}^{28}\end{array}$ & 83 & $\bar{F}$ & DLBCL & Complication & & Not reported & Surgery & Good \\
\hline $\begin{array}{l}\text { Islamoglu } \\
\text { et } \mathrm{al}^{29}\end{array}$ & 33 & $\mathrm{M}$ & AML & First sign & & $\begin{array}{l}\text { Bacteroides } \\
\text { fragilis }\end{array}$ & $\begin{array}{l}\text { Surgery; antibiotics (not otherwise } \\
\text { specified) }\end{array}$ & Died \\
\hline $\begin{array}{l}\text { Castellini } \\
\text { et } \mathrm{al}^{30}\end{array}$ & 54 & $\mathrm{M}$ & HL & Complication & & Not reported & $\begin{array}{c}\text { Surgery, metronidazole, } \\
\text { gentamycin, hyperbaric oxygen } \\
\text { therapy }\end{array}$ & Good \\
\hline $\begin{array}{l}\text { Yoshida et } \\
\mathrm{al}^{31}\end{array}$ & 16 & $\mathrm{M}$ & $\overline{A M L}$ & Complication & $\begin{array}{c}\mathrm{CB} \\
\text { transplantation } \\
\end{array}$ & P.aeruginosa & $\begin{array}{c}\text { Broad spectrum antibiotics (not } \\
\text { otherwise specified) }\end{array}$ & Died \\
\hline $\begin{array}{l}\text { Fukuno et } \\
\mathrm{al}^{32}\end{array}$ & $\begin{array}{l}43 \\
52 \\
53 \\
41\end{array}$ & $\begin{array}{l}M \\
M \\
F \\
F\end{array}$ & $\begin{array}{l}\text { APL } \\
\text { APL } \\
\text { APL } \\
\text { APL }\end{array}$ & $\begin{array}{l}\text { Complication } \\
\text { Complication } \\
\text { Complication } \\
\text { Complication }\end{array}$ & $\begin{array}{l}\text { ATRA } \\
\text { therapy } \\
\text { ATRA } \\
\text { therapy } \\
\text { ATRA } \\
\text { therapy } \\
\text { ATRA } \\
\text { therapy }\end{array}$ & $\begin{array}{c}\text { Not } \\
\text { Reported }\end{array}$ & $\begin{array}{l}\text { 'Antibiotic ointment' (not otherwise } \\
\text { specified) in the first two cases and } \\
\text { steroid in the last two patients. }\end{array}$ & $\begin{array}{l}\text { Good } \\
\text { Good } \\
\text { Good } \\
\text { Good }\end{array}$ \\
\hline $\begin{array}{l}\text { Bakshi et } \\
\mathrm{al}^{33}\end{array}$ & $\begin{array}{l}10 \\
6 \\
9\end{array}$ & $\begin{array}{l}\mathrm{M} \\
\mathrm{M} \\
\mathrm{M}\end{array}$ & $\begin{array}{l}\text { T-ALL } \\
\text { AML } \\
\text { NHL }\end{array}$ & $\begin{array}{l}\text { Complication } \\
\text { Complication } \\
\text { Complication }\end{array}$ & & $\begin{array}{l}\text { P.aeruginosa } \\
\text { P.aeruginosa } \\
\text { Not reported }\end{array}$ & $\begin{array}{l}\text { Ceftazidime, imipenem/cilastatin, } \\
\text { surgery } \\
\text { Imipenem/cilastatin } \\
\text { Imipenem, surgery }\end{array}$ & $\begin{array}{l}\text { Good } \\
\text { Good } \\
\text { Good }\end{array}$ \\
\hline $\begin{array}{l}\text { Mantadakis } \\
\text { et } \mathrm{al}^{34}\end{array}$ & 21 & $\mathrm{M}$ & ALL & Complication & & P.aeruginosa & $\begin{array}{c}\text { Meropenem,piperacillin/tazobactam, } \\
\text { metronidazole, linezolid, } \\
\text { voriconazole, colistin, surgery }\end{array}$ & Died \\
\hline $\begin{array}{l}\text { Lohana et } \\
\mathrm{al}^{35}\end{array}$ & 70 & $\mathrm{M}$ & $\begin{array}{l}\text { Mycosis } \\
\text { fungoides }\end{array}$ & First sign & & $\begin{array}{l}\text { Staphylococcus } \\
\text { aureus, E. coli, }\end{array}$ & Vancomycin, meropenem, surgery & Good \\
\hline
\end{tabular}




\begin{tabular}{|c|c|c|c|c|c|c|c|c|}
\hline & & & & & & $\begin{array}{c}\text { Group B } \\
\text { streptococci, } \\
\text { mixed anaerobes }\end{array}$ & & \\
\hline $\begin{array}{l}\text { Zhou et } \\
\mathrm{al}^{36}\end{array}$ & 49 & $\mathrm{M}$ & T-NHL & Complication & $\begin{array}{l}\text { Cutaneous } \\
\text { (penis) T- } \\
\text { NHL }\end{array}$ & Not reported & Interferon and ultraviolet B, surgery & Good \\
\hline $\begin{array}{l}\text { Naithani et } \\
\mathrm{al}^{37}\end{array}$ & $\begin{array}{l}23 \\
17 \\
17\end{array}$ & $\begin{array}{l}\mathrm{M} \\
\mathrm{M} \\
\mathrm{M}\end{array}$ & $\begin{array}{l}\text { APL } \\
\text { APL } \\
\text { APL }\end{array}$ & $\begin{array}{l}\text { Complication } \\
\text { Complication } \\
\text { Complication }\end{array}$ & $\begin{array}{c}\text { ATRA } \\
\text { therapy } \\
\text { ATRA } \\
\text { therapy } \\
\text { ATRA } \\
\text { therapy }\end{array}$ & $\begin{array}{c}\text { Not reported } \\
\text { Not reported } \\
\text { S.aureus, E.coli }\end{array}$ & $\begin{array}{l}\text { Local clotrimazole powdern (in all } \\
\text { cases). The second and third cases } \\
\text { received 'appropriate antibiotics' } \\
\text { (not otherwise specified) }\end{array}$ & $\begin{array}{l}\text { Good } \\
\text { Good } \\
\text { Good }\end{array}$ \\
\hline Oiso et $\mathrm{al}^{38}$ & 51 & $\mathrm{M}$ & AML & First sign & & $\begin{array}{l}\text { Corynebacterium } \\
\text { spp. }\end{array}$ & Cefpirome, clindamycin, cilastatin & Good \\
\hline $\begin{array}{l}\text { Kaya et } \\
\mathrm{al}^{39}\end{array}$ & 71 & $\mathrm{M}$ & NHL & Complication & $\begin{array}{c}\text { Intravascular } \\
\text { NHL }\end{array}$ & P.aeruginosa & $\begin{array}{c}\text { Surgery; antibiotics (not otherwise } \\
\text { speified) }\end{array}$ & Good \\
\hline $\begin{array}{l}\text { Durand et } \\
\mathrm{al}^{40}\end{array}$ & 53 & M & AML & Complication & & $\begin{array}{l}\text { Rhizopus } \\
\text { microsporus }\end{array}$ & $\begin{array}{l}\text { Piperacillin-tazobactam, } \\
\text { meropenem, amphotericin B, } \\
\text { micafungin, surgery }\end{array}$ & Died \\
\hline
\end{tabular}

Legend: M: male; F: female; AML: acute myeloid leukemia; APL: acute promyelocytic leukemia; NHL: non-Hodgkin’s lymphoma; DLBCL; diffuse large B-cell lymphoma; HL: Hodgkin’s lymphoma; ALL: acute lymphoblastic leukemia; ATRA;: all trans retinoic-acid; CB: cord blood; BMT: bone marrow transplantation

all-trans retinoic acid (ATRA) administration, a treatment able to induce high rates of complete remission and cure when used alone or in combination with cytotoxic treatments in APL. ${ }^{41}$ ATRA induce terminal differentiation of abnormal promyelocytes by activation of RAR $\alpha$ and by inducing degradation of promyelocytic leukemia (PML)/RAR ${ }^{42}{ }^{42}$ ATRA treatment is generally well tolerated. However, ATRA may cause leukocytosis and pulmonary complications, especially when used alone, with the possible development of the so-called "ATRA syndrome". ${ }^{43,44}$ In addition, some other major side-effects can occur, such as dryness of skin, liver dysfunction, hyperlipidemia, bone pain, headache, fever, pseudotumor cerebri and Sweet's syndrome. Scrotal ulcerations and necrotizing vasculitis may also be seen. ${ }^{25,45}$ It is reasonable to hypothesize that such lesions may progress to FG because of sovrainfections. Moreover, neutropenia may play a pathogenetic predisposing role. For those reasons, physicians must be aware that APL patients undergoing treatment with ATRA presenting with skin lesions may had necrotizing vasculitis needing carefully evaluation and prompt therapeutic approach.

Lymphoid malignancies, such as acute lymphoid leukemia (ALL), non-Hodgkin's lymphoma (NHL) and Hodgkin's lymphoma (HL), may be also complicated by FG that rarely, however, as reported above, may be the first sign of the disease. ${ }^{35}$

Moreover, FG has been observed in 2 patients with AML who underwent allogeneic bone marrow transplantation (allo-BMT), 2 patients with AML who underwent autologous (auto)-BMT, and one boy with refractory AML who underwent unrelated cord blood stem cell transplantation (CBT) ${ }^{23,31}$ All patients developed FG during the severe leukopenic phase of transplant (ranging from day +6 to day +25 , this latter in unrelated CBT). Of interest, the two patients who underwent auto-BMT were young women aged 25 and 26-years old, respectively. Moreover, in all but one case Pseudomonas aeruginosa was isolated from blood and tissue cultures, despite FG is generally due to a mixed aerobic and anaerobic bacterial flora. It has been speculated that severe and prolonged granulocytopenia may contribute to the development of FG associated to Pseudomonas aeruginosa infection. ${ }^{31}$

Finally, only two cases of FG complicating a non malignant hematologic disorder, such as immune thrombocytopenia (IT), have been published so far. In the first case, a 68-year-old man with diabetes mellitus who was diagnosed with IT and treated with steroids and high-dose Ig without response. On day +36 he developed FG of perineal abscess. ${ }^{47}$ Klebsiella pneumonia was cultured from the patient's blood and necrotizing tissue. The second one was an otherwise healthy 66-year-old man, in which steroids and highdose immunoglobulins were given with complete recovery of thrombocytopenia. ${ }^{46}$ However, on day +34 , while on tapering steroids, FG developed as a consequence of perineal abscess. After debridement, antibiotics and reconstructive surgery FG completely resolved and pletelet raised to normal levels that still is maintained after 5 months of follow-up.

Overall, therapy for FG complicating hematologic disorders does not differ from that used in the case of FG associated to other diseases.

Conclusions. FG is a rare necrotizing fasciitis of the perineum with a usually aggressive clinical course that may complicate hematologic malignancies and, sometimes, may presents as the first sign of the disease. Despite the progress in diagnosing and managing the 
disease, the mortality is still high, especially in hematologic patients with severe granulocytopenia. For that reason, early recognition of FG and prompt appropriate treatment have to be started as soon as possible. Finally, patients with APL receiving ATRA

\section{References:}

1. Vick R, Carson CC. Fournier's disease. Urologic Clin North Am. 1999; 26: 841-9. http://dx.doi.org/10.1016/S0094-0143(05)70224$\underline{X}$

2. Descamps V, Aitken J, Lee M. Hippocrates on necrotizing fasciitis. Lancet. 1994; 344: 556. http://dx.doi.org/10.1016/S01406736(94)91956-9

3. Fournier JA. Gangrene foudoyante de la verge. Medecin Practique. 1883; 4: 589-97.

4. Anaya DA, Dellinger EP. Necrotizing soft-tissue infection: diagnosis and management. Clin Infect Dis. 2007; 44: 705-10. http://dx.doi.org/10.1086/511638 PMid:17278065

5. Sarani B, Strong M, Pascual J, Schwab CW. Necrotizing fasciitis: current concepts and review of the literature. J Am Coll Surg. 2009; 208: 279-88. http://dx.doi.org/10.1016/j.jamcollsurg.2008.10.032 PMid:19228540

6. Mallikarjuna MN, Vijayakumar A, Patil VS, Shivswamy BS. Fournier's gangrene: current practices. ISRN Surgery. 2012; Article ID 942437. 8 pages.

7. Eke N. Fournier's gangrene: a review of 1726 cases. Br J Surg. 2000; 87: 718-28. http://dx.doi.org/10.1046/j.13652168.2000.01497.x PMid:10848848

8. Smith GL, Bunker CB, Dinneen MD. Fournier's gangrene. Br J Urol. 1998; 81: 347-55. http://dx.doi.org/10.1046/j.1464410x.1998.00532.x PMid:9523650

9. Clayton MD, Fowler JE Jr, Sharifi R, Pearl RK. Causes, presentation and survival of 57 patients with necrotizing fasciitis of the male genitalia. Surg Gynaecol Ostet. 1990; 170: 49-55. PMid:2294630

10. Hejase MJ, Simonin JE, Bihrle R, Coogan CL. Genitalia Fournier's gangrene: experience with 38 patients. Urology. 1996; 47: 734-9. http://dx.doi.org/10.1016/S0090-4295(96)80017-3

11. Rajbhandari SM, Wilson RM. Unusual infections in diabetes. Diabetes Res Clin Pract. 1998; 39: 123-8. http://dx.doi.org/10.1016/S0168-8227(97)00125-3

12. Laor E, Palmer LS, Tolla BM, Reid RE, Winter HI. Outcome prediction in patients with Fournier's gangrene. J Urol. 1995; 154: 89-92. http://dx.doi.org/10.1016/S0022-5347 (01)67236-7

13. Yilmazlar T, Ozturk E, Ozguc H, Ercan I, Vuruskan H, Oktay B. Fournier's gangrene: an analysis of 80 patients and a novel scoring system. Tech Coloproctol. 2010; 14: 217-23. http://dx.doi.org/10.1007/s10151-010-0592-1 PMid:20559857

14. Levenson RB, Singh AK, Novelline RA. Fournier's gangrene: role of imaging. RadioGraphics. 2008; 28: 519-28. http://dx.doi.org/10.1148/rg.282075048 PMid:18349455

15. Thwaini A, Khan A, Malik A, et al. Fournier's gangrene and its emergency management. Posgrad Med. 2006; 82: 516-9. http://dx.doi.org/10.1136/pgmj.2005.042069 PMid:16891442 PMCid:PMC2585703

16. Kabay S, Yucel M, Yaylak F, et al. The clinical features of Fournier's gangrene and the predictivity of the Fournier's Gangrene Severity Index on the outcomes. Int J Urol Nephrol. 2008; 40: 997$1004 . \quad$ http://dx.doi.org/10.1007/s11255-008-9401-4 PMid:18563618

17. Korkut M, Içöz $M$, Dayangaç $M$, et al. Outcome analysis in patients with Fournier's gangrene: report of 45 cases. Dis Colon Rectum. 2003; 46: 649-52. http://dx.doi.org/10.1007/s10350-0046626-x PMid:12792442

18. Ziser A, Girsh Z, Gozal D, Melamed Y, Adler M. Hyperbaric oxygen therapy for Fournier's gangrene- Crit Care Med. 1985; 13: 773-4. http://dx.doi.org/10.1097/00003246-198509000-00020 PMid:4028776

19. Patrizi A, Bandini G, Cavazzini G, Sommariva F, Veronesi S. Acute gangrene of the scrotum and penis in a patient with acute promyelocytic leukemia. A case of acute necrotizing gangrene. have to be monitored for signs and symptoms of FG because of the possibility of onset of onset of the appearance of genital ulcers and the onset of this severe complication. $^{48}$
Dermatologica. $\quad 1983 ; \quad 167: \quad 148-51$. http://dx.doi.org/10.1159/000249770 PMid:6578978

20. Joo P, Peters WJ. Fournier's gangrene. Can J Surg. 1985; 28: 1802. PMid:3971244

21. Berg A, Armitage JO, Burns CP. Fournier's gangrene complicating aggressive therapy for hematologic malignancy. Cancer. 1986; 57: 2291-4. $\quad$ http://dx.doi.org/10.1002/10970142(19860615)57:12<2291::AID-CNCR2820571210>3.0.CO;2-4

22. Radaelli F, Della Volpe A, Colombi M, Bregani P, Polli EE. Acute gangrene of the scrotum and penis in four hematologic patients. The usefulness of hyperbaric oxygen therapy in one case. Cancer. 1987; $60: \quad 1462-4 . \quad$ http://dx.doi.org/10.1002/10970142(19871001)60:7<1462::AID-CNCR2820600710>3.0.CO;2-A

23. Martinelli G, Alessandrino EP, Bernasconi P, et al. Fournier's gangrene: a clinical presentation of necrotizing fasciitis after bone marrow transplantation. Bone Marrow Transplant. 1998; 22: 10236. http://dx.doi.org/10.1038/sj.bmt.1701438 PMid:9849702

24. Faber HJ, Girbes AR, Daenen S. Fournier's gangrene as first presentation of promyelocytic leukemia. Leuk Res. 1998; 22: 4736. http://dx.doi.org/10.1016/S0145-2126(98)00025-3

25. Paydas S, Sahin B, Zorludemir S, Hazar B. All trans retinoic acid as the possible cause of necrotizing vasculitis. Leuk Res. 1998; 22 655-7. http://dx.doi.org/10.1016/S0145-2126(98)00062-9

26. Lévy V, Jaffarbey J, Aouad K, Zittoun R. Fournier's gangrene during induction treatment of acute promyelocytic leukemia, a case report. Ann Hematol. 1998; 76: 91-2. http://dx.doi.org/10.1007/s002770050370 PMid:9540765

27. Goto H, Tsurumi H, Kasahara S, et al. Acute promyelocytic leukemia accompanied by scrotal Fournier's gangrene during ATRA treatment and relapsed as external ear tumor. Rinsho Ketsueki. 1998; 39: 1169 -74. PMid:10028849

28. Yumura Y, Chiba K, Saito K, Hirokawa M. Fournier's gangrene in a patient with malignant lymphoma: a case report. Hinyokika Kiyo. 2000; 46: 7357.

29. Islamoglu K, Serdaroglu I, Ozgentas E. Co-occurrence of Fournier's gangrene and pancytopenia may be the first sign of acute myelomonocytic leukemia. Ann Plast Surg. 2001; 47: 352-3. http://dx.doi.org/10.1097/00000637-200109000-00031 PMid:11562053

30. Castellini C, De Nitto F, Bonomo S, et al. Fournier's gangrene in a patient with Hodgkin's disease: a clinical case. Chir Ital. 2001; 53: 905-8. PMid:11824071

31. Yoshida C, Kojima K, Shinagawa K, et al. Fournier's gangrene after unrelated cord blood stem cell transplantation. Ann Hematol. 2002; 81: 538-9. http://dx.doi.org/10.1007/s00277-002-0525-9 PMid:12373358

32. Fukuno K, Tsurumi H, Goto H, Oyama M, Tanabashi S, Moriwak $\mathrm{H}$. Genital ulcers during treatment with ALL-trans retinoic acid for acute promyelocytic leukemia. Leuk Lymphoma. 2003; 44: 200913. $\quad$ http://dx.doi.org/10.1080/1042819031000110982 PMid:14738157

33. Bakshi C, Banavali S, Lokeshwar N, Prasad R, Advani S Clustering of Fournier (male genital) gangrene cases in a pediatric cancer ward. Med Pediatr Oncol . 2003; 41: 472-4. http://dx.doi.org/10.1002/mpo.10110 PMid:14515393

34. Mantadakis E, Pontikoglou C, Papadaki HA, Aggelidakis G, Samonis G. Fatal Fournier's gangrene in a young adult with acute lymphoblastic leukemia. Pediatr Blood Cancer. 2007; 49: 682-4. http://dx.doi.org/10.1002/pbc.20695 PMid:16425246

35. Lohana P, Sharma H, Hemington-Gorse S, Boyce DE. Survival of skin graft in mycosis fungoides - a solution for a management dilemma. Ann R Coll Surg Engl. 2007; 89: W13-14. http://dx.doi.org/10.1308/147870807X227809 PMid:17958997 PMCid:PMC2121273

36. Zhou ZL, Wang CY, Xu ZS, Zheng BZ. Primary cutaneous T-cell 
lymphoma of the penis complicated by Fournier gangrene: a case report. Zhonghua Nan Ke Xue. 2008; 14: 542-4. PMid:18649756

37. Naithani R, Kumar R, Mahapatra M. Fournier's gangrene and scrotal ulcerations during all-trans-retinoic acid therapy for acute promyelocytic leukemia. Pediatr Blood Cancer. 2008; 51: 303-4. http://dx.doi.org/10.1002/pbc.21549 PMid:18421710

38. Oiso N, Rai S, Kawara S, Tatsumi Y, Kawada A. Genital infection as a first sign of acute myeloid leukemia. Case Rep Dermatol. 2010; 2: 18-21. http://dx.doi.org/10.1159/000279328 PMid:21173921 PMCid:PMC3004206

39. Kaya H, Yoshida T. A case of intravascular lymphoma complicated with Fournier's syndrome due to multidrug-reistant Pseudomonas aeruginosa. J Clin Exp Hematop. 2011; 51: 115-8. http://dx.doi.org/10.3960/jslrt.51.115

40. Durand CM, Alonso CD, Subhawong AP, et al. Rapidly progressive cutaneous Rhizopus microsporus infection presenting as Fournier's gangrene in a patient with acute myelogenous leukemia. Transpl Infect Dis . 2011; 13: 392-6. http://dx.doi.org/10.1111/j.1399-3062.2011.00601.x PMid:21443549 PMCid:PMC3593591

41. Huang ME, Ye YC, Chen SR, et al. Use of all-trans retinoic acid in the treatment of acute promyelocytic leukemia. Blood. 1988; 72: 567-72. PMid:3165295

42. Yoshida H, Kitamura K, Tanaka K, et al. Accelerated degradation of PML-retinoic acid receptor alpha (PML-RARA) oncoprotein by all-trans-retinoic acid in acute promyelocytic leukemia: possible role of the proteosome pathway. Cancer Res. 1996; 56: 2945-8. PMid:8674046

43. Patatanian E, Thompson DF. Retinoic acid syndrome: a review. J Clin Pharmacy Therap. 2008; 33: 331-8. http://dx.doi.org/10.1111/j.1365-2710.2008.00935.x PMid:18613850

44. Choudhry A, DeLoughery TG. Bleeding and thrombosis in acute promyelocytic leukemia. Am J Hematol. 2012; 87: 596-603. http://dx.doi.org/10.1002/ajh.23158 PMid:22549696

45. Tazi I, Rachid M, Quessar A, Benchekroun S. Scrotal ulceration following all-trans retinoic acid therapy for acute promyelocytic leukemia. Indian J Dermatol. 2011; 56: 561-3. http://dx.doi.org/10.4103/0019-5154.87156 PMid:22121279 PMCid:PMC3221224

46. Yuda J, Honma R, Yahagi T, Omoto E. Fournier's gangrene in a patients receiving treatment for idiopathic thrombocytopenic purpura. Int Med. 2011; 50: 2015-9. http://dx.doi.org/10.2169/internalmedicine.50.5323

47. D'Arena G, Cammarota A, Musto P. Fournier's gangrene complicating immune thrombocytopenia. Lancet (in press).

48. Yavasoglu I, Unubol M, Sargin G, Kadikoylu G, Bolaman Z. penile ulcer atra related in patients with acute promyelocytic leukemia. mediterr j Hematol Infect Dis. 2012; 4(1):e2012054. http://dx.doi.org/10.4084/MJHID.2012.054 PMid: 22973498 